\title{
Factors Predicting Retention In Care and Health Outcomes Among HIV Patients
}

\section{Merlene Ramnon}

Florida Department of Health, State, Wellington, Florida, United States

Objective

To provide knowledge on the factors that predict retention in care and health outcomes among HIV patients and be able to understand viral load and its relation to retention in care.

\section{Introduction}

The prevalence of persons living and diagnosed with HIV infection in the United States in 2010 to 2014 increased in number and rate (Center for Disease Control \& Prevention (CDC), 2016). In 2015, persons aged 25-29 years had the highest rate (33.4), followed by persons aged 20-24 years (31.2) (CDC, 2016). Consistent reduced viral load is associated with reduced morbidity and mortality and a lower likelihood of transmitting HIV to sex partners (CDC, 2011). Retention into HIV care promotes life and decreases the risk for HIV transmission (Yehia et. al. 2015). Preventing HIV transmission, prevention intervention strategy is critical and should be ongoing to all HIV patients consistently. New cases of HIV in the United States are increasing by approximately 30, 000 per year and with this increase, more providers are needed (Weiser et al.2016).

\section{Methods}

Quantitative cross sectional study: 2017 Palm Beach County Needs Assessment Survey was used, The data used was secondarydeidentified data. The sample size consisted of 357 survey participants. The surveys were collected from September 2016 to January 2017. The Florida Department of Health (FDOH) Institutional Review Board (IRB) approval was granted before data Collection.. The participants were not at risk due to de-indentifieddata. The demographic and clinical data was reviewed. Ethical practices were followed by securing data and only the data needed to conduct study were utilized.

The Independent Variables were: Age, Educational Level, Race, Gender, Condom Use, Unprotected sex, Sexual Orientation, Blood Tests-Viral Load, Medical care type facility. The Dependent Variables were: Medical Care/In Care, Miss HIV Meds and Hospitalization.

Four Research Questions are posed in this study, the results section list the research questions. Statistical Test were computed with the use of SPSS with ANOVA and Linear Regression

\section{Results}

RQ:Is there a statistical significant association between age of HIV patients, retention in care and health outcomes, in Palm Beach County?

Analysis of variance (ANOVA) was conducted to investigate if there was a statistical significant association between age of HIV patients and retention in care. Analysis Result: ANOVA, F $(9,0.393$. $)=2.181, p<0.05(p=0.023)$. There was statistically significant association between age and retention in care between groups. Post Hoc (Dunnett test revealed differences between the 50-54 $\mathrm{p}$ $=0.006$, between 55-59, $\mathrm{p}=0.009$ and $60 \geq \mathrm{p}=0.010$

RQ2: Is there a statistically significant association between HIV patients at risk for sexually transmitted diseases and retention in care as evidenced by unprotected sex?

Analysis of variance (ANOVA) was conducted to investigate if there was a statistical significant association between at risk for STD of HIV patients and retention in care as evidenced by unprotected sex.

Analysis Result: ANOVA, F (3, 4.531) =15.975, $\mathrm{p}<0.001(\mathrm{p}=0.000)$. There was statistically significant association between at risk for STD and retention in care as evidenced by unprotected sex .

SDS Annual Conference Proceedings 2019. This is an Open Access article distributed under the terms of the Creative Commons AttributionNoncommercial 4.0 Unported License (http://creativecommons.org/licenses/by-nc/3.0/), permitting all non-commercial use, distribution, and reproduction in any medium, provided the original work is properly cited. 
Post Hoc (Dunnett) test revealed differences between retention in care and risk for sexually transmitted diseases as evidenced by unprotected sex, $\mathrm{p}=0 \mathrm{RQ}$ : Are MSM HIV patients who attend health department clinics and or other health care facilities, more likely to retain in care than other groups of HIV patients?

Analysis of variance (ANOVA) was conducted to investigate if MSN patients who attend health department clinics and other health care facilities, more likely to retain in care than other groups of HIV patients?

ANOVA, $\mathrm{F}(4,0.280)=1.516, \mathrm{p}>0.05(\mathrm{p}=0.197)$. There was no statistically significant association between MSN HIV patients who attend health department clinics and other health care facilities than other groups of HIV patients more likely to remain in care?

RQ4: Do patients knowledge of viral load test predict retention in care?

Logistic Regression was conducted to investigate knowledge of viral load and retention in care. Retention in care and viral load tests regression model was statistically significant

The regression model showed $\mathrm{P}<0.01, \mathrm{p}=0.000$

Viral Load test significantly predicted retention in care. Coefficients of Viral Load greater than 1000 and Less than 200 were statistically significant: Viral Load

$>1000 \mathrm{p}=0.010 ;$ Viral Load $<200 \mathrm{p}=0.004$

\section{Conclusions}

Limitations to the study included the time frame to complete the study and the use of secondary data which was available to conduct the study. Low viral load is indicative of better health outcomes. Many studies have attempted to address barriers to retain in care and more work is needed to address the factors that impact retention in care.

Findings are consistent with other research that retention in care are due to social, behavioral and system factors. Some of the reasons the patients gave for their not in care are treatment of staff in clinic and or doctors office, long wait times, transportation, language barrier, child care and the clinic hours. The three most frequent answers were treatment of staff in clinic, long wait times and transportation. The burden o fnew HIV infection transmitting HIV if patients do not remain in care.

Findings are consistent with other research that retention in care are due to social, behavioral and system factors. Three most frequent answers were treatment by staff, long wait times and transportation.

\section{Acknowledgement}

\section{Florida Department of Health- Research Excellence Initiative}

2. Ryan White-Palm Beach County

3. Palm Beach County Health Department: Medical Director-Dr. Alina Alonso, Center Administrator-Ms. Lawanta Stewart and HIV Provider-Dr. Samuel Frimpong.

\section{References}

Center for Disease Control \& Prevention. Diagnoses of HIV infectionin the United States and dependent areas, 2015 HIV Surveillance Report, 2016; 27.

Drachler ML, Drachler CW, Teixeira LB, Leite JCD. 2016. The Scale of Self-Efficacy Expectations of Adherence to Antiretroviral Treatment: A Tool for dentifying Risk for Non-Adherence to Treatment for HIV. PLoS One. 11(2), e0147443. PubMed https://doi.org/10.1371/journal.pone.0147443

Kambugu, A., Zhang, Y., Braitstein, P., Christopoulos, K.A...Martin, J.N. (2010). Retention in care among HIV infected patients in resource- limited settings: Emerging insights and new directions.

Current HIV/AIDS Report, 2010; 7(4), 234-244.

Roscoe C, Hachey DM. Topic 8: Retention in HIV Care. National HIV Curriculum, 2017.

ISDS Annual Conference Proceedings 2019. This is an Open Access article distributed under the terms of the Creative Commons AttributionNoncommercial 4.0 Unported License (http://creativecommons.org/licenses/by-nc/3.0/), permitting all non-commercial use, distribution, and reproduction in any medium, provided the original work is properly cited. 
ISDS 2019 Conference Abstracts

Thompson MA, Mugavero MJ, Amico KR, Cargill VA, Chang LW, et al. 2012. ...Nachega, J.B. Guidelines for improving entry into and retention in care and antiretroviral adherence for persons with HIV: Evidence- based recommendations from an international association of physicians in AIDS care panel. Ann Intern Med. 156(11), 817-33. PubMed https://doi.org/10.7326/0003-4819-156-11-201206050-00419

Weiser J, Beer L, West BT, Duke CC, Gremel GW, et al. 2016. Qualifications, demographics, satisfaction and future capacity of the HIV care provider workforce in the United States, 2013- 2014. Clin Infect Dis. 63(7), 966-75. PubMed https://doi.org/10.1093/cid/ciw442

Yehia BR, Stewart L, Momplaisir F, Mody A, Holtzman CW. 2015. Shea, J.A. Barriers and facilitators to patient retention in HIV care. BMC Infect Dis. 15, 246. PubMed https://doi.org/10.1186/s12879-015-0990-0

Logistic Regression Result

\begin{tabular}{|c|c|c|c|c|}
\hline Model & DF & Mean Square & F & 17.663 \\
\hline Regression & 2 & 3.005 & $0.000 \mathrm{~b}$ \\
\hline Residual & 353 & .170 & \\
\hline Total & 355 & & \\
\hline
\end{tabular}

Results of Logistic Regression

Linear Regression

\begin{tabular}{|c|c|c|c|c|c|}
\hline Model & $\mathbf{R}$ & RSquare & $\begin{array}{c}\text { Adjusted R } \\
\text { Square }\end{array}$ & $\begin{array}{c}\text { Standard Error of } \\
\text { Estimates }\end{array}$ & $\begin{array}{l}\text { Durbin } \\
\text { Watson }\end{array}$ \\
\hline 1 & $.032 \mathrm{Bb}$ & .091 & .086 & .41244 & 1.803 \\
\hline b. Dependent Variable: Medical Care & & & & & \\
\hline
\end{tabular}

Results of Linear Regression 